\title{
Global economic burden of schizophrenia: response to authors' reply
}

\author{
This article was published in the following Dove Press journal: \\ Neuropsychiatric Disease and Treatment \\ 14 February 2017 \\ Number of times this article has been viewed
}

\section{Amanda L Neil' \\ Vaughan J Carr ${ }^{2,3}$}

'Menzies Institute for Medical Research, The University of Tasmania, Hobart, TAS, ${ }^{2}$ Research Unit for Schizophrenia Epidemiology, University of New South Wales, Sydney, NSW, ${ }^{3}$ Department of Psychiatry, School of Clinical Sciences, Monash University, Melbourne, VIC, Australia
Correspondence: Amanda L Neil

Menzies Institute for Medical

Research, 17 Liverpool Street, Hobart,

TAS 7000, Australia

Tel +6I 362264640

Email amanda.neil@utas.edu.au

\section{Dear editor}

For clarification, we undertook bottom-up costing using individual participant data from the Low Prevalence Disorders Study in our costing study. ${ }^{1}$ We did not use the data reported in the study by Carr et $\mathrm{al}^{2}$ as asserted by Chong et al. ${ }^{3}$ Chong et al have thus misunderstood and thus misrepresented our methodology in both their systematic review $^{4}$ and their response to our letter. ${ }^{5}$

\section{Disclosure}

The authors report no conflicts of interest in this communication.

\section{References}

1. Carr VJ, Neil AL, Halpin SA, Holmes S, Lewin TJ. Costs of schizophrenia and other psychoses in urban Australia: findings from the Low Prevalence (Psychotic) Disorders Study. Aust N ZJ Psychiatry. 2003;37(1):31-40.

2. Carr VJ, Johnston PJ, Lewin TJ, Rajkumar S, Carter GL, Issakidis C. Patterns of service use among persons with schizophrenia and other psychotic disorders. Psychiatr Serv. 2003;54(2):226-235.

3. Chong HY, Teoh SL, Wu DB, Kotirum S, Chiou CF, Chaiyakunapruk N. Global economic burden of schizophrenia: a systematic review. Neuropsychiatr Dis Treat. 2016;12:357-373.

4. Chong HY, Teoh SL, Wu DB, Kotirum S, Chiou CF, Chaiyakunapruk N. Authors' reply. Neuropsychiatr Dis Treat. 2016;12:3071-3072.

5. Neil AL, Carr VJ. Global economic burden of schizophrenia: letter in response. Neuropsychiatr Dis Treat. 2016;12:3069-3070. 


\section{Authors' reply}

Huey Yi Chong'

Nathorn Chaiyakunapruk ${ }^{1-4}$

'School of Pharmacy, Monash University Malaysia, Selangor, Malaysia; ${ }^{2}$ Center of Pharmaceutical Outcomes Research (CPOR), Department of Pharmacy Practice, Faculty of Pharmaceutical Sciences, Naresuan University, Phitsanulok, Thailand; ${ }^{3}$ School of Pharmacy, University of Wisconsin, Madison, USA; ${ }^{4}$ School of Population Health, University of Queensland, Brisbane, Australia

Correspondence: Nathorn Chaiyakunapruk School of Pharmacy, Monash University Malaysia, Jalan Lagoon Selatan, 46I50 Bandar Sunway, Selangor, Malaysia

Email nathorn.chaiyakunapruk@monash.edu

\section{Dear editor}

We thank Dr Neil and Professor Carr for their clarification on the data source used in their study. ${ }^{1}$ In this regard, we would like to highlight one of the most common challenges when conducting any systematic review, for example economic burden of schizophrenia in this case - the marked diversity in reporting among the included studies, which increases the likelihood of any potential misinterpretation. In convergence with a number of published systematic reviews of economic burden studies, ${ }^{2-5}$ there has been a consistent call for a more explicit reporting in various aspects of an economic burden study, thus readability and transparency can be enhanced. However, a standardized guide/checklist for conducting and reporting economic burden is yet to be available. On the final note, we strongly urge for the development of such a guidance document to improve the quality and clarity of an economic burden study.

\section{Disclosure}

The authors report no conflicts of interest in this communication.

\section{References}

1. Carr VJ, Neil AL, Halpin SA, Holmes S, Lewin TJ. Costs of schizophrenia and other psychoses in urban Australia: findings from the Low Prevalence (Psychotic) Disorders Study. Aust N Z J Psychiatry. 2003; 37(1):31-40.

2. Cooper NJ. Economic burden of rheumatoid arthritis: a systematic review. Rheumatology (Oxford). 2000;39(1):28-33.

3. Ng CS, Lee JY, Toh MP, Ko Y. Cost-of-illness studies of diabetes mellitus: a systematic review. Diabetes Res Clin Pract. 2014;105(2):151-163.

4. Kleine-Budde K, Touil E, Moock J, Bramesfeld A, Kawohl W, Rossler W. Cost of illness for bipolar disorder: a systematic review of the economic burden. Bipolar Disord. 2014;16(4):337-353.

5. Luppa M, Heinrich S, Angermeyer MC, König H-H, Riedel-Heller SG. Cost-of-illness studies of depression. J Affect Disord. 2007;98(1): $29-43$.

Dove Medical Press encourages responsible, free and frank academic debate. The content of the Neuropsychiatric Disease and Treatment 'letters to the editor' section does not necessarily represent the views of Dove Medical Press, its officers, agents, employees, related entities or the Neuropsychiatric Disease and Treatment editors. While all reasonable steps have been taken to confirm the content of each letter, Dove Medical Press accepts no liability in respect of the content of any letter, nor is it responsible for the content and accuracy of any letter to the editor.

\section{Publish your work in this journal}

Neuropsychiatric Disease and Treatment is an international, peerreviewed journal of clinical therapeutics and pharmacology focusing on concise rapid reporting of clinical or pre-clinical studies on a range of neuropsychiatric and neurological disorders. This journal is indexed on PubMed Central, the 'PsycINFO' database and CAS, and is the official journal of The International Neuropsychiatric Association (INA). The manuscript management system is completely online and includes a very quick and fair peer-review system, which is all easy to use. Visit http://www.dovepress.com/testimonials.php to read real quotes from published authors. 